\title{
Effect of decidual tissue on the uterine production of prostaglandins in pseudopregnant rats
}

\author{
V. D. Castracane* and A. A. Shaikh $\dagger$ \\ Worcester Foundation for Experimental Biology, Shrewsbury, Massachusetts 01545, U.S.A.
}

\begin{abstract}
Summary. The concentration of prostaglandin F (PGF) in uterine vein plasma of non-traumatized pseudopregnant rats and pseudopregnant rats with deciduomata were not significantly different from each other at any of the times of pseudopregnancy studied (Days 7, 10 and 12). There was a significant increase in PGF levels on Day 10 in both groups of pseudopregnant animals $(P<0.05)$ compared to the Day 4 values, and PGE values were significantly greater on Day 10 in the decidual tissue-bearing rats $(P<0 \cdot 01)$. A slight but not significant elevation in PGE concentration was observed on Days 7 and 12 in rats with deciduomata, but there was no significant difference in the control rats on Days $4,7,10$ or 12 . The results indicate that the prolongation of pseudopregnancy in rats with deciduomata is not due to a decreased production of uterine PGs and lend support to the recent suggestion of a luteotrophic effect of decidual tissue in the rat.
\end{abstract}

\section{Introduction}

In the rat, pseudopregnancy is prolonged by hysterectomy or by the presence of deciduomata (see DeFeo, 1967). In the hysterectomized rat it is assumed that the removal of the uterine luteolysin is related to this prolongation. The assumption has also been made that the presence of the decidualized uterus prevents the production of the luteolytic substance and thus accounts for the prolonged pseudopregnancy (Melampy et al., 1964). Since the study of Melampy et al. (1964) evidence has accumulated to indicate that a prostaglandin (PG), particularly PGF-2 $\alpha$, may be the uterine luteolysin (see review by Pharriss et al., 1972). The present study was undertaken to determine the concentration of PGE and PGF in uterine vein plasma of pseudopregnant rats with or without deciduomata, and to ascertain if decreases in the uterine production of PGs is responsible for the prolongation of pseudopregnancy in these animals.

\section{Materials and Methods}

Mature female rats of the Sprague-Dawley strain, weighing 150-200 g, were received from the Charles River Breeding Laboratories and maintained under standard animal housing conditions on a $14 \mathrm{hr}$ light: $10 \mathrm{hr}$ dark photoperiod. Vaginal smears were taken daily and only animals with regular cycles were used. Rats were made pseudopregnant by cervical stimulation on the evening of prooestrus and the morning of oestrus; the day of oestrus was designated as Day 1 of pseudopregnancy. Control animals received no further treatment. A decidual response was induced in 'experimental' animals by scratching the endometrium under ether anaesthesia on Day 4 of pseudopregnancy (DeFeo, 1966). Uterine vein cannulations were performed between 09.00 and 11.00 hours' as previously described (Shaikh \& Saksena, 1973) on Days 4, 7, 10 and 12 in the non-traumatized pseudopregnant rats and on Days 7,10 and 12 in rats with deciduomata. Uterine vein blood was collected

\footnotetext{
* Present address: Department of Reproductive Biology, Case Western Reserve University, School of Medicine, Cleveland, Ohio 44106, U.S.A.

$\dagger$ Present address: Southwest Foundation for Research and Education, 8848 W. Commerce Street, San Antonio, Texas 78284, U.S.A.
} 
for $10-15$ min and plasma was quickly obtained by centrifugation and was stored at $-20^{\circ} \mathrm{C}$ until assayed.

The plasma was extracted by the method of Skarnes \& Harper (1972) and the PGF and PGE separated on silicic acid columns (Caldwell et al., 1971). Radioimmunoassay of PGF was performed by the method of Stylos et al. (1972) and PGE as described by Stylos et al. (1974). It was not possible with the antiserum to PGF to distinguish between PGF-1 $\alpha$ and PGF- $2 \alpha$ since the former crossreacts $>75 \%$; the results are therefore expressed as PGF equivalents. The PGE values are given as PGE equivalents, although there was only a $22 \%$ cross-reaction for PGE-2 with the PGE-1 antiserum. The sensitivity of the assays was $50 \mathrm{pg}$ for PGF and $25 \mathrm{pg}$ for PGE. All radioimmunoassays were corrected for $100 \%$ recovery by the addition of trace amounts of labelled standards before extraction.

Statistical analyses were made using Student's $t$ test.

\section{Results}

The concentrations of PGF (Table 1) in uterine vein plasma were not significantly different from each other in the control and experimental rats at any of the times studied (Days 7, 10 and 12). There was a significant increase in uterine vein PGF on Day 10 in both groups $(P<0.05)$ compared to the Day 4 values.

The concentration of PGE (Table 1) in uterine vein plasma was significantly greater in the rats with deciduomata than in the controls on Day $10(P<0.01)$. Concentrations of PGE were elevated slightly but not significantly on Days 7 and 12 in the experimental rats, but did not vary significantly in the control rats on any day.

Table 1. Mean ( + S.E.M.) concentrations $(\mathrm{ng} / \mathrm{mI})$ of PGF and PGE in uterine vein plasma during pseudopregnancy in rats (no. in group in parentheses) with (experimental) or without (control) deciduomata

\begin{tabular}{|c|c|c|c|c|}
\hline & \multicolumn{2}{|c|}{ PGF } & \multicolumn{2}{|c|}{ PGE } \\
\hline & Control & Experimental & Control & Experimental \\
\hline Day 4 & $4 \cdot 31 \pm 0.58(7)$ & - & $0.65 \pm 0.11(7)$ & - \\
\hline Day 7 & $4.02 \pm 1.28(8)$ & $3.99 \pm 0.60(8)$ & $0.90 \pm 0.31(8)$ & $1.39 \pm 0.23(7)$ \\
\hline Day 10 & $* 6.30 \pm 0.62(8)$ & $* 6.60 \pm 0.80(8)$ & $0.49 \pm 0.04(8)$ & $+2.32 \pm 0.55(8)$ \\
\hline Day 12 & $5 \cdot 03 \pm 1 \cdot 15(5)$ & $4 \cdot 31 \pm 1 \cdot 59(7)$ & $0.70 \pm 0.22(5)$ & $0.98 \pm 0.12(7)$ \\
\hline
\end{tabular}

* Significantly different from Day 4 levels at $P<0 \cdot 05$.

$\dagger$ Significantly different from control values on the same day at $P<0 \cdot 01$.

\section{Discussion}

These results demonstrate that the prolonged pseudopregnancy associated with decidualization of the rat uterus is not related to any decreased production of PGs at the times studied, although the prolongation of pseudopregnancy in the hysterectomized rat may still be due to the removal of the source of the uterine luteolysin. The normal termination of pseudopregnancy in the rat after 12-13 days (12.6 \pm 0.3 days in our colony) may be related to the significant increases in PGF concentration seen in uterine vein plasma on Day 10. Removal of the uterus up to Day 10 of pseudopregnancy allows a prolonged pseudopregnancy to follow, but hysterectomy late on Day 10 or afterward results in a progressive decline in the incidence of prolonged pseudopregnancy (Silbiger \& Rothchild, 1963), indicating that the uterine luteolytic effect may first become manifest on or about Day 10 and have a cumulative effect during the next few days. This possibility agrees well with the increased concen- 
tration of PGF found on Day 10. In a study similar to the present one, but with a higher frequency of sampling, Weems et al. (1974) also found PGF in uterine tissue and in uterine vein plasma to be highest on Day 10; these authors also found that uterine PG production was not decreased by decidualization.

The lack of variation of PGE concentration in uterine vein plasma throughout pseudopregnancy suggests that the $\mathrm{E}$ series of $\mathrm{PGs}$ are not important contributors to the uterine luteolytic effect in the rat. The statistically higher levels of PGE concentrations in the uterine vein plasma of the experimental rats than in the control rats on Day 10 is probably specifically associated with the decidualization process, since the concentration of PGE-2 in rat decidual tissue has been reported to be many times greater than that found in uteri without decidual tissue (Lindner et al., 1974). Under the same conditions PGF was only slightly elevated (U. Zor, personal communication). In the decidualized uterus the pattern of PGE and PGF production is markedly different in response to the same hormonal milieu, suggesting that the control of PGE production is different from that of PGF.

Since the intrauterine infusion of 14- or 15-day sheep embryos will significantly prolong the oestrus cycle in sheep (Rowson \& Moor, 1967), the possibility of an anti-luteolytic substance produced by the conceptus has been suggested. Similarly, the rat is more resistant to termination of pregnancy by PGs at certain stages of pregnancy (Fuchs \& Mok, 1973), suggesting some anti-luteolytic action of unknown origin. A luteotrophic rather than just an anti-luteolytic function has been attributed to decidual tissue in the pseudopregnant rat (Rothchild et al., 1974; Gibori et al., 1974) because increased progesterone levels are associated with the presence of decidual tissue, a phenomenon not seen in hysterectomized pseudopregnant rats (Hashimoto et al., 1968; Rothchild \& Gibori, 1976) even though the period of pseudopregnancy is similarly extended.

These results indicate that the prolongation of pseudopregnancy in rats bearing decidual tissue is not due to a decreased production of uterine PGs, and lend support to the suggestion that decidual tissue has a luteotrophic effect in the rat.

This study was supported in part by the Steroid Training Program Grant 5 T01 AM-05564 from the National Institute of Health and a contract grant No. CSD/2837 from the United States Agency for International Development. Dr E. K. Inskeep and Dr U. Zor kindly allowed us to read their manuscripts before publication. Thanks are due to Mrs Karen Moore and Mrs Shamin Shaikh for their assistance.

\section{References}

Caldwell, B.V., Burstein, S., Brock, W. \& Speroff, L. (1971) Radioimmunoassay of the F prostaglandins. J. clin. Endocr. Metab. 33, 171-175.

DeFeo, V.J. (1966) Vaginal-cervical vibration: a simple and effective method for the induction of pseudopregnancy in the rat. Endocrinology 79, 440442.

DeFeo, M.J. (1967) Decidualization. In Cellular Biology of the Uterus, pp. 191-290. Ed. R. M. Wynn. Appleton-Century-Crofts, New York.

Fuchs, A.-R. \& MoK, E. (1973) Prostaglandin effects on rat pregnancy. II. Interruption of pregnancy. Fert. Steril. 24, 275-283.

Gibori, G., Rothchild, I., Pepe, G.J., Morishige, W.K. \& LAM, P. (1974) Luteotrophic action of decidual tissue in the rat. Endocrinology 95, 11131118.

Hashimoto, I., Hendricks, D.M., Anderson, L.L. \& Melampy, R.R. (1968) Progesterone and pregn-4en-20a-ol-3-one in ovarian venous blood during various reproductive states in the rat. Endocrinology 82, 333-341.
Lindner, H.R., Zor, U., Bauminger, S., TSAFriRi, A., LAMPrecht, S.A., Koch, Y., ANTEBI, S. \& ACHWARTZ, A. (1974) The use of prostaglandin synthetase inhibitors in the analysis of the role of prostaglandins in reproductive physiology. In Prostaglandin Synthetase Inhibitors, pp. 271-287. Eds H. J. Robison \& J. R. Vane. Raven Press, New York.

Melampy, R.M., Anderson, L.L. \& Kragt, C.L. (1964) Uterus and life-span of rat corpora lutea. Endocrinology 74, 501-504.

Pharriss, B.B., Tillson, S.A. \& Erickson, R.R. (1972) Prostaglandins in luteal function. Recent Prog. Horm. Res. 28, 51-89.

RothCHILD, I. \& GIBORI, G. (1976) The luteotrophic effect of decidual tissue: the stimulatory effect of decidualization on the serum progesterone level of pseudopregnant rats. Endocrinology (in press).

Rothchild, I., Gibori, G.M., PePe, G.J., Morishige, W.K., Lam, P., Velasco, M.E. \& Castracane, V.D. (1974) Secretion of a luteotrophic hormone by decidual tissue in the rat. Program, 56 th $A$. Meeting, Endocrine Society, A-169. 
Rowson, L.E.A. \& MooR, R.M. (1967) The influence of embryonic tissue homogenate infused into the uterus, on the life-span of the corpus luteum in the sheep. J. Reprod. Fert. 13, 511-516.

ShaikH, A.A. \& Saksena, S.K. (1973) Cyclic changes in uterine venous and peripheral plasma levels of F prostaglandins correlated with peripheral progesterone levels in the golden hamster. Adv. Biosci. 9, 635-639.

Silbinger, M. \& RothChild, 1. (1963) The influence of the uterus on the corpus luteum-pituitary relationship in the rat. Acta endocr., Copenh. 43, 521-538.

SKARNES, R.C. \& HARPER, M.J.K. (1972) Relationship between endotoxin induced abortion and the synthesis of prostaglandin F. Prostaglandins 1, 191-203. Stylos, W., Burstein, W., Rivetz, B., Gunsalus, P. \& SKARNes, R. (1972) The production of anti-F prostaglandin serum and its use in radioimmunoassay. Intrasci. Chem. Rep. 6, 67-71.

Stylos, W., Howard, L., Ritzi, E. \& Skarnes, E. (1974) The preparation and characteristics of PGE antiserum. Prostaglandins 6, 1-31.

Weems, C.W., Pexton, J.E., Butcher, R.L. \& Inskeep, E.K. (1974) Effect of decidual tissue on prostaglandin $\mathrm{F}$ in the pseudopregnant rat. Program, 7th A. Meeting Soc. Study. Reprod., p. 161.

Received 14 March 1975 